\title{
The importance of geotechnical research in building projects: case study sustainable rural housing
}

\section{La importancia de la investigación geotécnica en los proyectos de edificaciones: caso de estudio vivienda rural sustentable}

\author{
RODRÍGUEZ-URIBE, Juan Carlos $\dagger^{*}$, SERRANO-ARELLANO, Juan and TREJO-TORRES, Zaira \\ Betzabeth
}

Instituto Tecnológico Superior de Huichapan-ITESHU-TecNM, Architecture Division, Dom. Conocido S / N, El Saucillo, Huichapan, Hgo, Mexico. C.P. 42411.

ID $1^{\text {st }}$ Author: Juan Carlos, Rodríguez-Uribe / CVU CONACYT ID: 166235

ID $1^{\text {st }}$ Co-author: Juan, Serrano-Arellano / Researcher ID Thomson: F-1060-2013

ID $2^{\text {nd }}$ Co-author: Zaira Betzabeth, Trejo-Torres / CVU CONACYT ID: 774137

DOI: $10.35429 / J A D .2021 .14 .5 .19 .26$

Received July 20, 2021; Accepted December 30, 2021

\begin{abstract}
When conceiving the project of a building, we understand that it will be interacting with the ground through a "soilstructure" system, and that it will be the appropriate interaction between the ground and the foundation that will guarantee functionality and stability from the geotechnical perspective as structural of the project. Today we identify buildings that present problems concerning structural stability due to a deficient geotechnical study that entails a negative impact from the point of view of safety, functionality and economics of the project. The professional in charge to determine the geotechnical conditions of a site is the Geotechnical Engineer or Engineer specializing in Soil Mechanics, in fact, it must be a professional with comprehensive training with knowledge in various disciplines such as geotechnics, structures, foundations and construction. The document with which we base ourselves to establish the guidelines to follow from an analysis and design perspective is the geotechnical study. This document also allows us to understand the possible threats to which the project will be at some point and how to carry out the analysis and design of the buildings, so that they can interact in perfect harmony with their surroundings. By means of a case study concerning the project of a sustainable rural house, we show the stages and elements that make up the report of the geotechnical study that was carried out, indicating the development, analysis and methodology of the study, as well as the various elements that comprise it.
\end{abstract}

Geothecnical, Architecture, Project

\section{Resumen}

Al concebir el proyecto de una edificación, comprendemos que la misma estará interactuando con el terreno mediante un sistema "suelo-estructura", y que será la adecuada interacción entre el terreno y la cimentación la que garantizará la funcionalidad y estabilidad desde la perspectiva geotécnica como estructural del proyecto. Hoy en día identificamos edificaciones que presentan problemas concernientes a la estabilidad estructural debido a un deficiente estudio geotécnico que conlleva a un impacto negativo desde el punto de vista de seguridad, funcionalidad y económico del proyecto. El profesionista encargado para dictaminar las condiciones geotécnicas de un sitio es el Ingeniero Geotécnico o Ingeniero especialista en Mecánica de Suelos, en realidad debe ser un profesional con formación integral con conocimientos en varias disciplinas tales como geotecnia, estructuras, cimentaciones y construcción. El documento con el cual nos basamos para establecer las pautas a seguir desde una perspectiva de análisis y diseño es el estudio geotécnico. Este documento nos permite, además, comprender las posibles amenazas a las cuales estará sometida el proyecto y el cómo realizar el análisis y diseño de las edificaciones, de forma tal que puedan interactuar en perfecta armonía con su entorno. Por medio de un caso de estudio concerniente al proyecto de una vivienda rural sustentable evidenciamos las etapas y elementos que conforman el informe del estudio geotécnico que se llevó a cabo indicando el desarrollo, análisis y metodología del estudio, así como los diversos elementos que lo integran.

Geotecnia, Arquitectura, Proyecto

Citation: RODRÍGUEZ-URIBE, Juan Carlos, SERRANO-ARELLANO, Juan and TREJO-TORRES, Zaira Betzabeth. The importance of geotechnical research in building projects: case study sustainable rural housing. Journal Architecture and Design. 2021. 5-14:19-26.

\footnotetext{
* Correspondence to Author (E-mail: jcrodriguez@iteshu.edu.mx)

$\dagger$ Researcher contributing as first author.
} 


\section{Introduction}

In most of the bibliographic sources specialized in geotechnics and city regulations in which construction regulations are dictated, the need to carry out field exploration and laboratory research complemented with engineering analysis on the use of physical and mechanical properties is highlighted. and hydraulics of the soils and on the construction process, to achieve an adequate interaction between the support ground and the structure.

For some, this practice may seem unnecessary for "small-scale" projects. However, and regardless of the magnitude of the project, experience has shown us that many failures, losses of time and money are due, for the most part, to the lack of geotechnical studies or incomplete studies [1].

The most important reason to carry out the geotechnical study is to have a reasonable safety for the work, at the lowest possible cost, thus avoiding setbacks and delays during construction.

The complementary technical standard for the design of foundations 2017 of the RCDF establishes that every geotechnical study must include a memory where the soil is described in detail, the foundation to be used is justified, the analysis methods used and results according to these standards. The description of the expected behavior of the foundation in each of the limit states must be included, in addition to attaching the results of the explorations, laboratory tests, magnitudes considered for design and expected future behavior of the construction and neighboring properties.

In general, two types of geotechnical studies are considered: At a preliminary level, to obtain an approximation to the geotechnical characteristics of a land, to establish the feasibility of construction of a project, including geotechnical threats, general foundation criteria and works for the adequacy of ground. At the definitive level, for design and construction purposes for a specific project, in accordance with regulations [1].
The geotechnical study includes two fundamental aspects: Investigation of the subsoil, which includes the study and knowledge of its geological origin, field exploration and field and laboratory tests necessary to quantify the physical, mechanical and hydraulic characteristics of the soil. Engineering analysis, includes the technical interpretation that allows the characterization of the subsoil and the evaluation of the possible failure mechanisms that make it possible to supply the parameters and the necessary recommendations for the design and construction of the foundations and other works related to the subsoil [ 1].

The definitive geothenic study must contain at least the following aspects:

Regarding the project: Identification, location, objective of the study, general description of the project, structure system and loads.

Regarding the subsoil: Summary of the research carried out, terrain morphology, geological origin, stratigraphy, physicalmechanical characteristics, groundwater level, with an analysis of its impact on the behavior of the project. Geotechnical analysis: at this point the analyzes are summarized and the geotechnical criteria adopted to determine limit states of failure, failure modes, etc., are justified.

Design recommendations: include type of foundation, depth of offset, bearing capacity, differential settlements and calculated totals, stratigraphic profile, etc.

Recommendations for construction: procedures for construction, tolerances, instrumentation, verification and controls [1]. 


\section{Methodology}

It is proposed to establish an organized and clear methodology that allows determining how it is intended to meet the objectives proposed in this document, this, in order to identify and analyze the technical requirements that must be followed for the formation of a definitive geotechnical study, in addition to be able to structure, develop and evaluate a case study which was carried out in a practical way for a real situation. Therefore, the procedure will be carried out through 3 stages as evidenced in Figure 1.

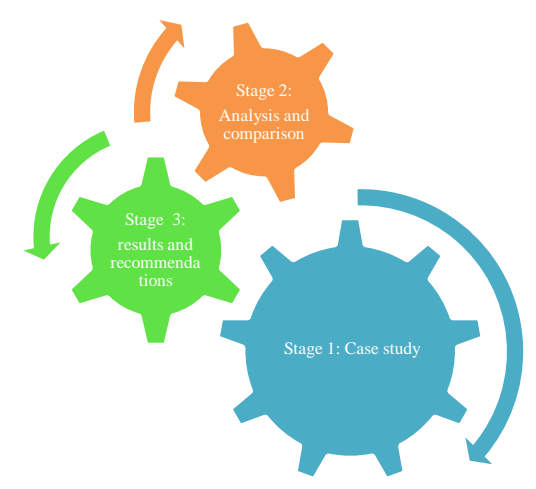

Figure 1 Geotechnical study / analysis methodology Source: Own authorship

When developing this methodological system, it is sought not only to establish and determine a structural order for the execution of the soil studies carried out, but also to evaluate and verify its functionality and correct applicability in terms of procedures, techniques and other activities that are often used. In this way, said procedure will be carried out as shown below.

\section{Field exploration}

The exploration of the subsoil corresponds to the first phase of geotechnical studies in general, this phase basically consists of making open-pit wells in the land under which the proposed project will be executed in order to determine the stratification of the soil and thus, to be able to obtain samples, whether altered or unaltered, for analysis in the laboratory. The company "Laboratorio de control para la Construcción S.A. de C.V. " For its part, it carried out the drilling with a manual equipment for drilling the open pit by mechanical means (pick and shovel). The samples, in general, are of the unaltered type, which determines the tests to be carried out [3].

\section{Testing and laboratory}

In order to be able to determine the main properties and characteristics of the soil, the company makes use of field tests and laboratory tests as is generally recommended. For the analysis of the gravimetric properties, the tests of natural humidity, unit weight, specific gravity, Atterberg limits and granulometric distributions are carried out.

Regarding the soil resistance parameters, simple compression, consolidation and triaxial tests were carried out to obtain the resistance parameters of the granular material.

\section{Case study}

\section{Background}

The services of a specialized geotechnical laboratory were requested to carry out a geotechnical-mechanical study of soils on the land where the rural housing project will be located. The land is located within the facilities of the Higher Technological Institute of Huichapan. The purpose of this study is to know the physical characteristics of the subsoil up to the analyzed depth, to determine the loadbearing capacity of the natural ground in a stratum, and to provide recommendations for the type of foundation and its depth of abutment.

\section{Project location}

The project to be carried out is located $8.15 \mathrm{~km}$ in a straight line to the municipal seat of the municipality of Huichapan, with a heading of $45.55^{\circ} \mathrm{NE}$, in the state of Hidalgo. Its geographical location is $99^{\circ} 42$ ' $21.56^{\prime}$ " of West longitude and $20^{\circ} 19^{\prime} 24.61^{\prime \prime}$ of North latitude, with an altitude of 2155 m.s.n.m. Figure 2 shows the location of the study site. 


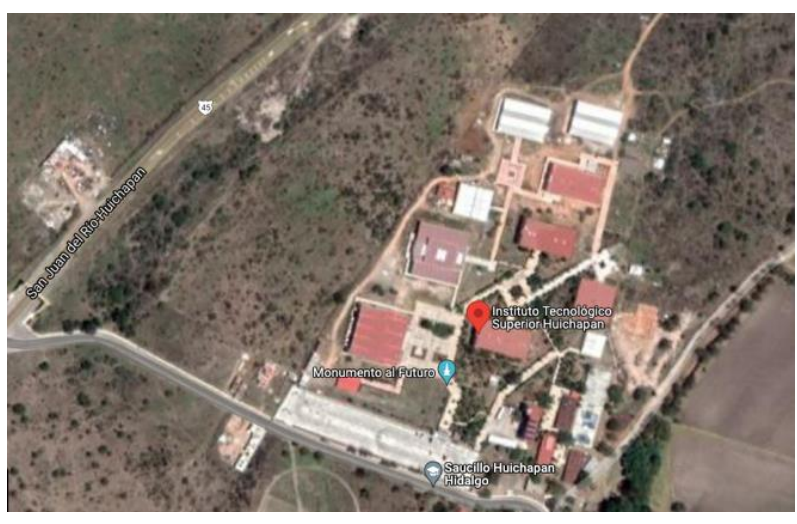

Figure 2 View of the terrain location Source: Google Maps

\section{Site conditions}

The topography of the property under study is flat, with a slight downward slope from southeast to northeast.

It is recommended to reference the surface level of the natural terrain in the analyzed site with the project level bench.

The surface geology at the study site corresponds to sandstone sedimentary rock (ar) as well as the presence of igneous rock.

Figure 3 shows the surface geology of the site in the geological - mining chart F14CF78 from INEGI [2].

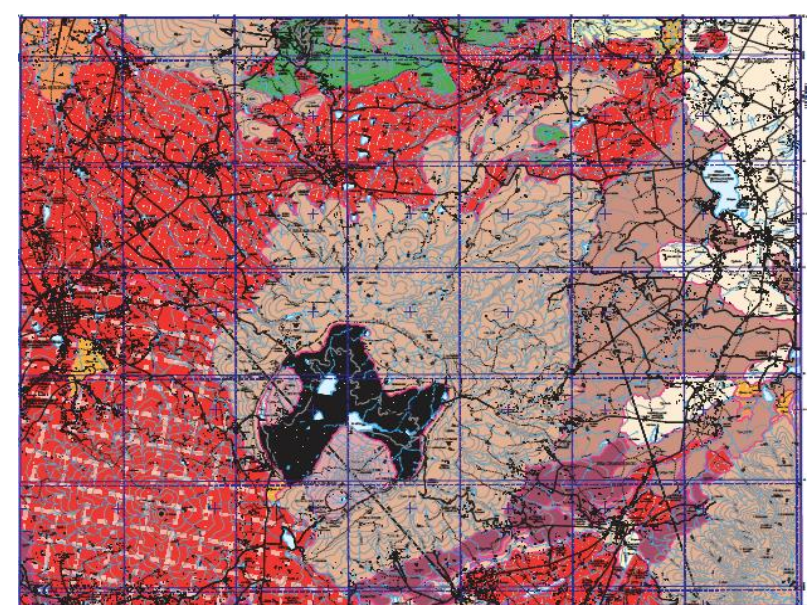

Figure 3 Surface geology of the study area Source: INEGI

\section{Description of the project (architectural and overall plan)}

The project to be built in the study area corresponds to a rural house which will be built within the facilities of the Higher Technological Institute of Huichapan (ITESHU), in the town of El Saucillo, Municipality of Huichapan in the state of Hidalgo. This project consists of a total of $59.30 \mathrm{~m} 2$ built, equipped with a functional distribution of each architectural area, solving the needs of each of the possible inhabitants of this project, the prototype is of a single level, making it stand out due to the combination of slabs as it contains slabs inclined at a slope of $16 \%$ and straight or flat slabs.

The project will be carried out with the sole purpose of providing a home and meeting the necessary needs to carry out the daily activities of certain people who at some possible time may inhabit this house. Therefore, it is intended to carry out an effective and efficient project, thus causing the need to study and analyze more thoroughly the soil of the property where it is intended to move said construction, to know the quality of the materials to be used and the degrees of compaction of the soil already once modified.

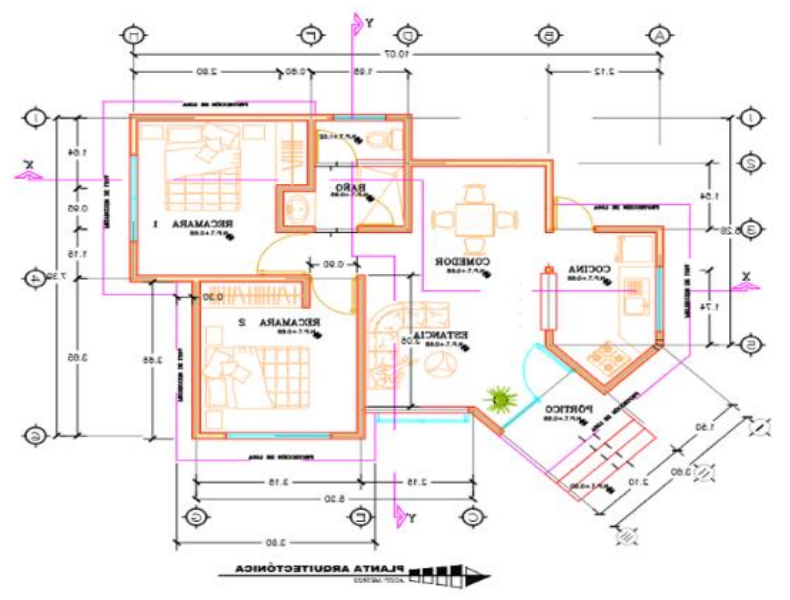

Figure 4 Architectural plan of social interest type house Source: Own authorship

\section{Investigation}

For the purpose of the exploration of the terrain, an open pit was carried out with the help of mechanical equipment to a depth of $0.65 \mathrm{~m}$, suspending at that depth due to finding materials that can hardly be excavated with the equipment used. 
Figure 5 shows the physical site where the geotechnical study (open pit) was carried out within the facilities of the academic center.

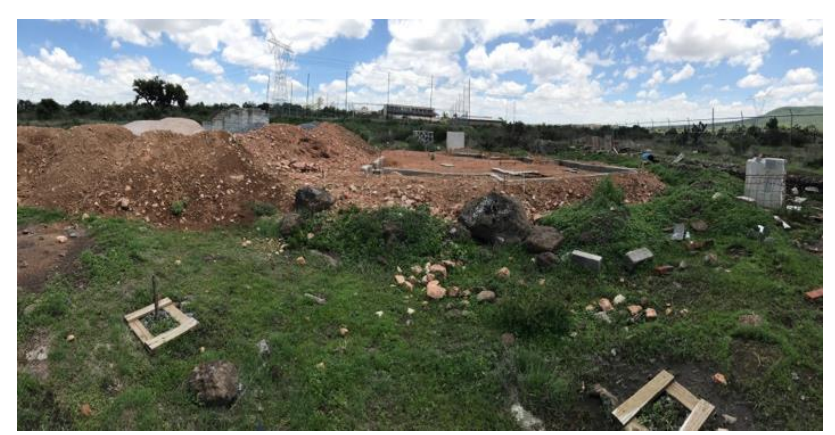

Figure 5 Site within the academic center where the geotechnical studies were carried out

Source: Google Maps

First, a visual inspection of the walls of the well was carried out to proceed with the sampling of the materials.

From the horizon of the soil profile in the exploration area, samples of the altered type and small samples of the unaltered type were obtained, which were transferred to the laboratory to obtain the following parameters: natural water content, liquid limit, plastic limit, plastic index, particle size composition, SUCS classification, solid density, void ratio, degree of saturation and natural volumetric weight. Figure 6 shows the open pit exploration well located in the study area.

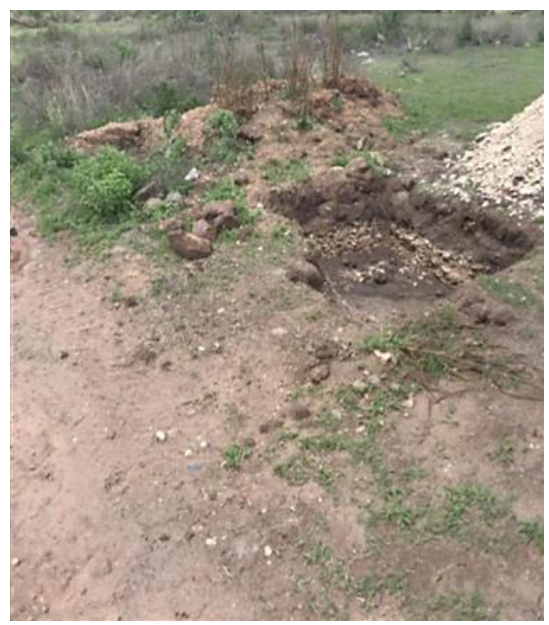

Figure 6 Open pit exploration well

Source: Own authorship

At the beginning of the third stratum of natural terrain, at a depth of between 0.30 to $0.60 \mathrm{~m}$ with respect to the current surface level, fragments of the volcanic tuff found were obtained, which were determined for shear stress resistance.

\section{Characterization of the subsoil}

Taking as a reference the current surface level of the natural terrain. Stratigraphy up to the analyzed depth can be described as follows:

In the first stratum of natural terrain, it occurs between depths of 0.00 to $0.15 \mathrm{~m}$, being composed of a mixture of sand and yellowishbrown clay, with traces of vegetable matter, classified according to the unified soil classification system (SUCS) of SC [3].

The second stratum of natural terrain found in the exploration, occurs between depths of 0.15 to $0.30 \mathrm{~m}$, being composed of a mixture of clay and sand of medium compressibility of dark brown color, classified according to the unified soil classification system (SUCS) of CL [3].

The third and last stratum of natural terrain found in the exploration, which occurs from $0.30 \mathrm{~m}$ and up to the explored depth of $0.65 \mathrm{~m}$, is composed of a consolidated, stratified volcanic tuff, of a light yellowishbrown color, which when extracted is classified as a mixture of gravel, sand and silt, classified according to GM's Unified Soil Classification System (SUCS) [3].

Until the depth explored, the groundwater level was not found. Figure 7 shows the walls of the open-pit exploration well carried out in the area of the project.

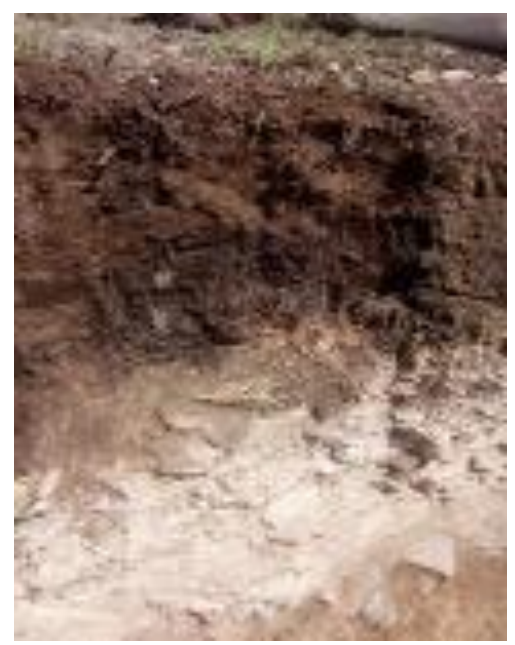

Figure 7 View of the walls of the open pit exploration well

Source: Own authorship 
In Figure 8 we identify by means of the stratigraphic profile the materials present in the subsoil of the area where the ground is ruled.

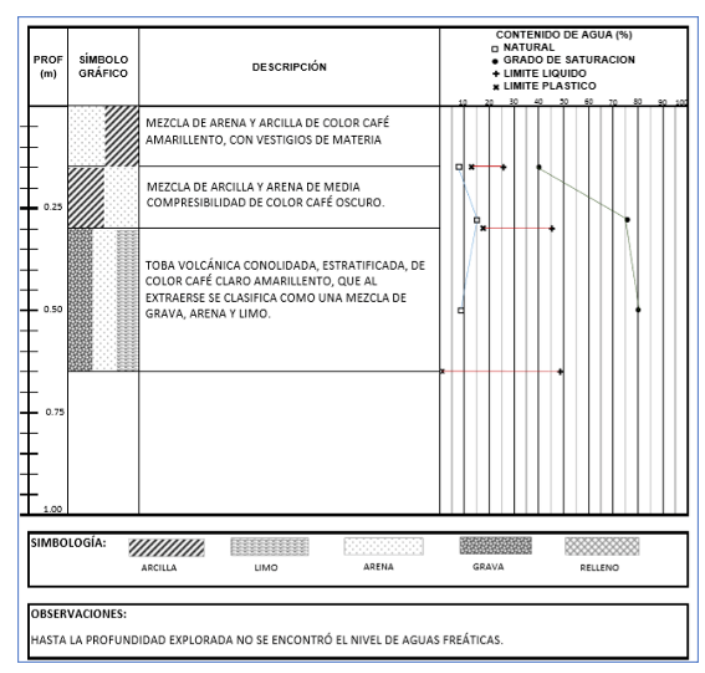

Figure 8 View of the stratigraphic profile of the open heat well

Source: Own authorship

\section{Permissible load capacity of natural terrain}

To the fragments of volcanic tuff obtained at the beginning of the third stratum of natural terrain, at a depth of between 0.30 to $0.60 \mathrm{~m}$ with respect to the current surface level, the load capacity was estimated using Terzaghi's theory [4], based on the results obtained from the unconfined simple compression test. The admissible load capacity of the land for the design of the foundation for its upward movement in the third stratum, which in the analyzed site, which occurs from a depth of $0.30 \mathrm{~m}$, is $1.66 \mathrm{Kg} / \mathrm{m}^{2}$.

\section{Seismic coefficient}

Taking into account the regional geology and the stratigraphic conditions determined in this work, and in accordance with the design manual for civil works, earthquake design, edited by the Federal Electricity Commission (CFE) [5], the spectrum for design Seismic for structures of Group A (schools), for the seismic zone B of the country and for a type II soil (intermediate terrain) that is the one that corresponds to it, is presented in the following Table 1 .

\begin{tabular}{|c|c|c|c|c|c|c|}
\hline $\begin{array}{c}\text { Seismic } \\
\text { Zone }\end{array}$ & $\begin{array}{l}\text { Soil } \\
\text { Type }\end{array}$ & $\mathbf{a}_{0}$ & c & $\begin{array}{r}\mathbf{T}_{\mathbf{a}} \\
(\mathbf{S})\end{array}$ & $\begin{array}{l}\mathbf{T}_{\mathbf{b}} \\
(\mathbf{S})\end{array}$ & $\mathbf{r}$ \\
\hline $\mathrm{B}$ & II & 0.08 & 0.30 & 0.3 & 1.5 & $2 / 3$ \\
\hline
\end{tabular}

Table 1 Seismic coefficients Source: Own authorship
Where "a 0 " is the ground acceleration coefficient, "c" is the seismic coefficient and $t$ is the natural period of interest: " $\mathrm{T}_{\mathrm{a}}$ " and " $\mathrm{T}_{\mathrm{b}}$ " are two characteristic periods that delimit the plateau, and " $r$ " is the exponent that defines the curved part of the design spectrum. Figure 9 shows the seismic regionalization in Mexico. The seismic regions in Mexico are divided into four zones, which are classified according to the frequency and intensity of the earthquakes. A) Low seismic zone, B) Moderate seismic zone, C) High seismic zone and D) Severe seismic zone. The seismic coefficient for the design of the structures is considered a significant value due to its way of acting in the analysis for the dimensioning of these. The seismic coefficient for the design of the structures is considered a significant value due to its way of acting in the analysis for the dimensioning of them. The seismic coefficient, $\mathrm{c}$, is the quotient of the horizontal shear force that must be considered acting at the base of the structure as a result of the earthquake, divided by the weight of the latter above said level. To this end, the level from which its displacements with respect to the surrounding terrain begin to be significant should be taken as the basis of the structure.

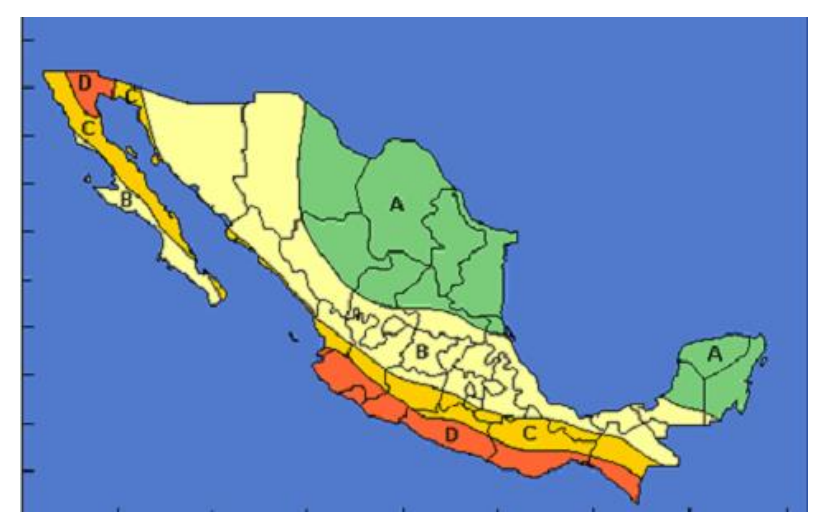

Figure 9 Seismic regionalization in Mexico Source: Manual for the design of civil works, earthquake design, Federal Electricity Commission (C.F.E.), 1993 


\section{Results}

Recommended type of foundation.

According to the results obtained from the different tests carried out on the materials recovered in the exploration, the stratigraphy that the terrain presents in the explored site and the characteristics of the project to be built, it is concluded that the foundation of the structure is composed by means of isolated reinforced concrete footings joined by means of counter beams, by continuous reinforced concrete footings, or by a combination of both. It is also recommended that the design of the foundation be carried out for each section with a different load, in order that the loads of the structure are transmitted to the ground in a uniform way, to avoid areas with higher concentrations of load and thus limit settlements. spreads. Finally, the project's structural designer will define the type of foundation based on the loads and the way in which they are transmitted to the subsoil.

\section{Recommended tread depth}

A total thickness of $0.30 \mathrm{~m}$. Will be eliminated from the construction area, the second layer corresponding to clays with expansive characteristics, which, when presenting changes in their water content, present changes in their volume, which would cause movements in the structure and in the floors; This increase in water content may be due to a leak in the drinking water supply or drainage pipes, caused by rain, excessive irrigation of green areas, neighboring properties, etc.

Then, the floor of the excavation will be that of the beginning of the third layer of natural terrain that is identified with the yellowish light brown color then, the floor of the excavation will be that of the beginning of the third layer of natural terrain that is identified with the brown color clear yellowish.

The second stratum of natural land, according to "the ghazzaly and Vijayvergiya criteria for predicting the expansion potential in clays", is $2.5 \%$ expansion.

The grounding of the foundation of the structure will be in the third layer of natural terrain, which in the explored site occurs from a depth of $0.30 \mathrm{~m}$ and is identified with a light yellowish-brown color.
The value of $1.66 \mathrm{Kg} / \mathrm{m}^{2}$, obtained in the natural terrain at the recommended depth for its uplift, will be used as the admissible load capacity of the ground for the design of the foundation.

The foundation will rest on a poor concrete template $\left(\mathrm{f}^{\prime} \mathrm{c}=100 \mathrm{Kg} / \mathrm{cm}^{2}\right), 5 \mathrm{~cm}$ thick, in order to transmit the loads more uniformly to the ground, to increase the distance between the reinforcing steel of the foundation and the natural terrain, thereby reducing the oxidation of the steel, in addition to protecting the supporting soil against its weathering during the execution of the works, and working on a smooth surface that lends itself to the proper placement of the steel and that be able to clean thoroughly before placing the foundation concrete.

To support the floors, an embankment will be built with Inert material (tepetate), compacted to at least $90 \%$ with respect to its weight.

Maximum dry specific (standard aashto test), in layers no greater than $20 \mathrm{~cm}$ thick to ensure uniform compaction, and no less than 10 $\mathrm{cm}$ to avoid coating (fatigue) of the layer. The total thickness of this layer depends on the levels of the excavation and the finished floor.

\section{Conclusions}

Geotechnical studies must always be carried out previously for the construction of all types of buildings.

The geotechnical study can be preliminary or definitive. In the first, it is about evaluating the land to determine the feasibility of executing a work or knowing its geological characteristics or performing soil quality zoning; The geotechnical study at a definitive level is carried out for design and construction purposes.

The magnitude and content of the geotechnical study depends on the importance and disposition of the foundation of the work and the complexity of the soil conditions.

Geotechnical studies allow obtaining information concerning the following aspects: 
Determine the soil profile and the geotenic characteristics of the subsoil and estimate its mechanical behavior under the project loads.

Estimate the settlements that the building has to experience.

Classify the type of soil in the area where the building will be located (fine soil coarse soil) and the conditions in which it is found (expansion, dispersivity, collapsibility, to name a few).

Analyze the feasible foundation alternatives, taking into consideration safety, technical variability, construction process and behavior over time.

Obtain the basis for the seismic design recommendations [1].

The definitive geotechnical studies developed by the company "Laboratorio de Control para la Construcción S.A. de C.V. " They adequately meet the established requirements, not only by current legal regulations, but also, due to what the scientific literature proposes regarding geotechnical analyzes and their derivatives,

In the development of the definitive geotechnical studies, the phases corresponding to the field work (field exploration and tests) represent a fundamental and vital part, because the results obtained from these will be made available through the geotechnical analysis, therefore, it is important to emphasize field work at a general level and try to minimize as much as possible the methodological errors that may occur, in order to be able to carry out a more precise characterization of the soil properties and thus be able to provide a comprehensive and adequate solution through a functional foundation system that is capable of supporting the loads generated by a structure to the ground [3] .

\section{Thanks}

We appreciate the work of the company "control laboratory for construction S.A. de C.V." who developed the geotechnical study of the present investigation.

\section{References}

[1] Guardo Polo, J. (2011). Estudios geotécnicos Una necesidad en obras civiles. Revista Científica Ingeniería y Desarrollo, (6), 117-126.

[2] Carta F14-CF78 Geológica_Minera (INEGI).

[3] Gil Ariza, J. D. (2018). Conceptualización de la metodología de un estudio geotécnico definitivo con base en la literatura científica y la normativa legal vigente

[4] Juárez Badillo, Eulalio., \& Rico Rodríguez, A. (2001). Mecánica de Suelos, Tomo I. Limusa, México DF.

[5] Braja, M. (2001). Principios de ingeniería de cimentaciones. Ed. Thomson SA México.

[6] Manual de diseño de obras civiles. Diseño por sismo. Comisión Federal de Electricidad (CFE). 